\title{
Viral Infections and Diabetes Mellitus
}

$$
\text { الاصابات الفيروسيه و مرض السكري }
$$

\begin{tabular}{|c|c|c|}
\hline Abdulatif Albaitushi & Ghassaq Tariq* & Mohammed Mahmood* \\
\hline & ze of Medicine/ Erbil Uni & \\
\hline & gy Research Center / AL- & ain University \\
\hline محمد محمود* & كلية الطب / جامعة طارقيل & عبد اللطيف البيتوشي \\
\hline
\end{tabular}

\section{Abstract}

(Jype-1-diabetes (T1D) is known to be caused by progressive destruction of pancreatic B-cells, genetic factors are believed to play a major role in the disease development, however, environmental factors are also implicated in the pathogenesis, viruses are one of these factors, as well as triggering beta-cells specific autoimmunity, viruses may cause diabetes by directly infecting and destroying beta-cells, 14 different viruses have been reported to be associated with the development of T1D. In this work, the relationship between (T1D) and seropositivity to three viruses (CMV, EBV and HCV) have been studied, the sera of 54 T1D patients and controls under the age of 30 from both sexes have been investigate for the presence of IgG antibodies against CMV, EBV and total antiHCV antibodies (Abs). Results revealed that $94.4 \%$ of the T1D patients were infected with CMV, 61.1\% were infected with $\mathrm{EBV}$ and $35.1 \%$ were infected with HCV. While among the control group it was found that $77 \%$ were infected with CMV comparing to $92.5 \%$ and $3.7 \%$ were infected with $\mathrm{EBV}$ and $\mathrm{HCV}$, respectively. Out of the 54 diabetics $8(14.8 \%)$ found to be infected with the three viruses while none of the controls found to have such seropositivity. From those results it may be concluded that neither the CMV nor the EBV has a relation with T1D while the infection with HCV may be contributed to T1D since there is a significant difference $(p<0.001)$ between the number of T1D patients and number of controls who have anti-HCV Abs.

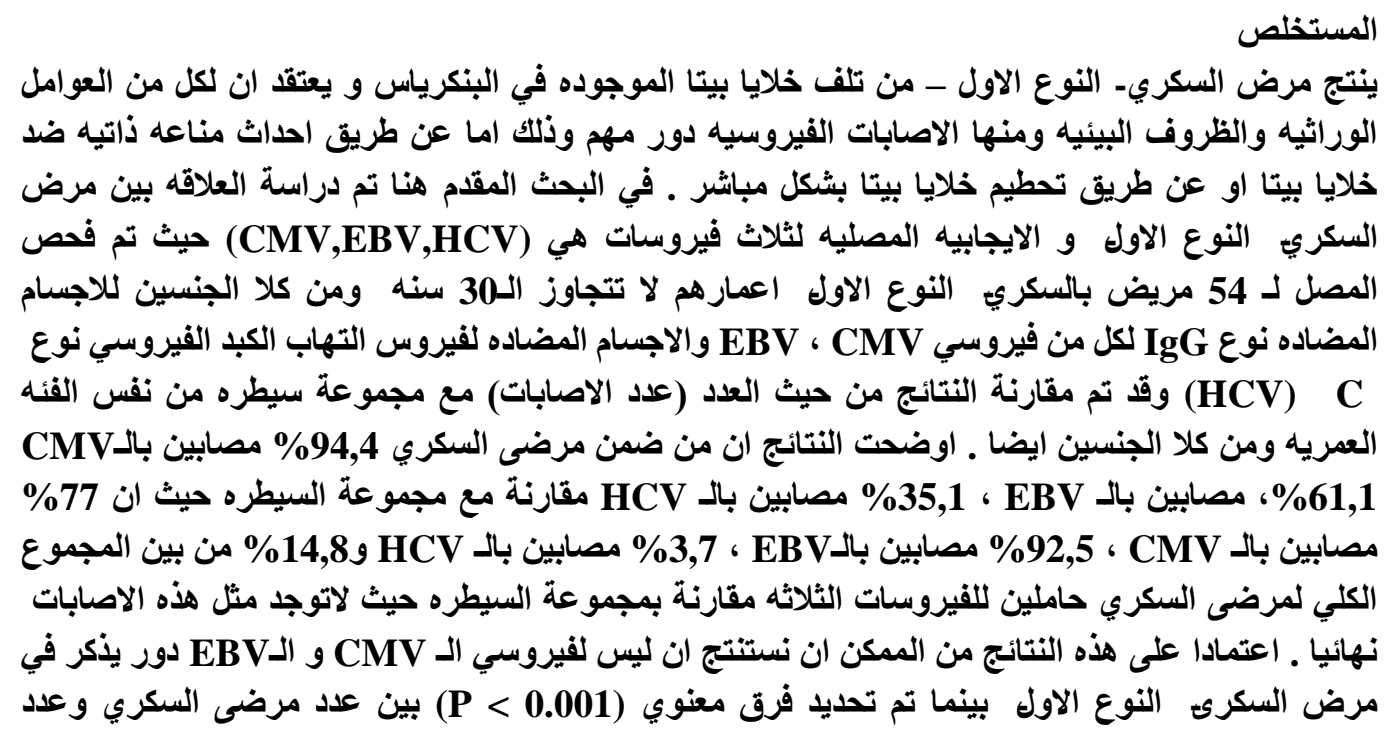




\section{الاشخاص من مجموعة السيطره الحاملين للاجسام المضاده لقيرروس الـHCV مما يدل على ان الاصابه

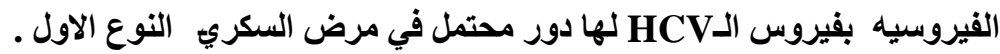

\section{Introduction}

Type-1-diabetes (T1D) also known as insulin-dependent diabetes mellitus (IDDM) or juvenile onset diabetes results from the progressive destruction of pancreatic beta cells resulting in insulin deficiency [1,2]. Genetic factors are thought to be a major component for the development of T1D [3], however studies on the risk of developing T1D using identical twins have shown that the concordance rate for the disease approaches only 40\% [4], suggesting that the environmental factors including climate, exposure to pathogens, particularly viruses [5] and beta cells toxins may be involved in the initiation and/or progression of beta cells destruction leading to T1D [6].

The earliest observations for the suggestion of virus contribution to T1D is that the onset of T1D sometimes follow acute infections and occurs with greater frequencies at certain times of the year which often indicate a viral cause, recent studies showed the presence of virus-specific IgM antibodies in recent- onset T1D patients. The most convincing evidence comes from studies in which viruses isolated from the pancreas of patients who died from acute T1D [7].

Till now over a half dozen of human viruses have been reported to be associated with human T1D, these include enteroviruses (Coxsackie B virus), Rubella virus, Mumps virus, CMV, EBV, VZV, Retro virus, Rota virus and HIV, several researchers reported that veterans in care with HIV are at higher risk of DM than the United state population in general $[8,9,10]$.

The implication of CMV in T1D was achieved through a number of clinical studies; a case report described a child with congenital CMV infection, and a woman with CMV infection who both developed T1D then after developed extensive pancreatitis [7]. It is possible that molecular mimicry may be involved in some cases of CMV induced diabetes, in this situation immune response against similar epitopes shared by antigenic determinants of CMV and islet-cell specific proteins may lead to islet-cell specific autoimmunity. Evidence for this is the finding that human CMV can induce an islet-cell antibody that reacts with a $38 \mathrm{kD}$ autoantigen expressed in human pancreatic islet [11].

EBV had also been reported as a causative agent of autoimmune diseases [12]. There is some evidence that EBV may be potentially capable of triggering autoimmune T1D by molecular mimicry, an (11) aminoacid sequence of the EBV protein, BOLF1, was found to be homologous to residues in the Asp-57region of the HLA-DQw8 beta chain peptide [13].

Hepatitis-C particularly genotype 2a clearly predisposes to DM [14], Preliminary studies suggest that hepatitis-C virus infection may be a risk factor for the development of DM, that diabetes was observed in $21 \%$ of $\mathrm{HCV}$-infected patients compared with $12 \%$ of $\mathrm{HBV}$-infected subjects, in diabetes cohort $4.2 \%$ of patients were found to be infected with HCV compared to $1.6 \%$ of control group [15].

The major mechanisms appear to be strongly predictive of diabetes are the insulin resistance related to fibrosis and family history of diabetes (inheritance) [16]. 
In addition, demonstration of the specific endocrine abnormalities associated with $\mathrm{HCV}$ infection and improvement in glucose tolerance during antiviral therapy would strengthen the association of HCV infection and diabetes [15].

\section{Materials and methods}

This study comprised 54 sample taken from patients previously diagnosed as Insulin Dependent Diabetes Mellitus (IDDM) patients whom their age is less than 30 years old, from both sexes with male: female (M: F) ratio 28-26, the second group is the control group which consist of 27 blood samples taken from healthy volunteers of the same age group and with 17-10 (M: F) ratio.

Blood samples were collected in anticoagulant -free tubes, centrifuged at 3000rpm/15 min, each sample was liquated in several eppendorf tubes and stored at-20 $\mathrm{C}^{\circ}$ ( to avoid multiple freezing/ thawing process).

Enzyme-linked immunosorbent assay (ELISA), with chromogenic substrate, was used to detect the presence of anti-CMV-IgG antibodies (bioactive diagnostic, Hamburg, Germany), anti-EBV-IgG antibodies (human gesellschaft fürbiochemica diagnostic mbh, Wiesbaden, Germany) and total anti-HCV-Abs antibodies (DRG diagnostic, Germany) Using ELISA system (ASYS company, Austria /2007).

\section{Statistical analysis}

Data was statistically analyzed using chi-square test and ANOVA test using SPSS program, version 11.5 .

\section{Results}

Results revealed that 8 out of the $54(14.8 \%)$ diabetics were infected with the three viruses, five of them were males whom their age ranging between (14-20) year old, and 3 females between (6-19) years old, while none of the controls (0\%) carrying the three viruses simultaneously.

It was found also that $94.4 \%$ of T1D patients and $77 \%$ of the control group were infected with CMV. Moreover, $61.1 \%$ of T1D patients were found to be infected with EBV comparing to $92.5 \%$ among controls, referring to the absence of any significant difference $(\mathrm{P}>0.05)$ between patients and controls for both of CMV and EBV. On the other hand, $35.1 \%$ of diabetics were found to be infected with HCV comparing to only $3.7 \%$ among the control group, indicating a highly significant difference $\left(\mathrm{P}^{<} 0.001\right)$, Figure(1).

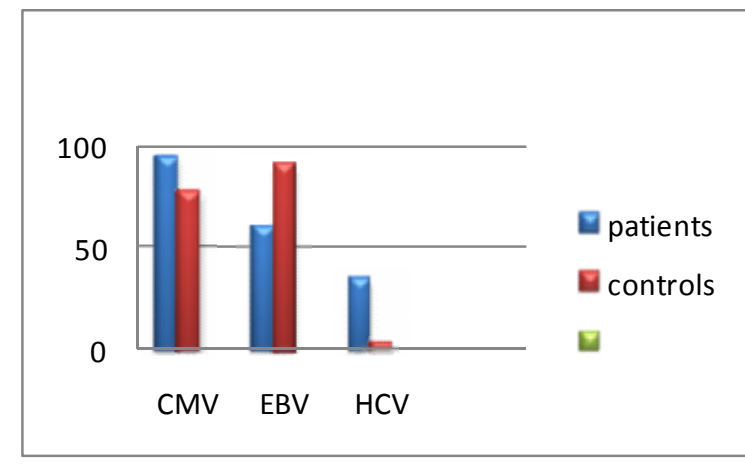

Fig (1): comparison in the percentage of viral infections between DM patients and healthy controls 
By using the ANOVA (analysis of variants) - F test, SPSS program version 11.5 to identify the significant difference of the variable means among the three groups, it was found that there is a significant difference between the mean values of $\operatorname{IgG}$ titer of the three viruses (CMV, EBV and total anti- HCV antibodies) comparing to their control groups $(\mathrm{P}=0.009,0.001$ and 0.048$)$, respectively.

\section{Discussion}

Results of ANOVA test showed the presence of considerable differences between the mean values of IgG titer of diabetics and healthy controls, pointing to the possible role of viral infection (in general) in diabetes mellitus.

As it was expected that the use of ELISA test to study the role of CMV and EBV in the diagnosis of TID serologically with no or a little benefit since a wide variety of diseases are associated with infection by CMV \& EBV. Moreover, the infection with CMV and EBV in both healthy and DM patients in Iraqi population was found to be very high, that resulted in the absence of significant differences between those two groups, more studies on such viruses and other members of herpes family are recommended.

Primary infection and reactivated disease by a given virus may involve different cell types and present different clinical pictures. It may conclude that another method could be used for studying the role of these two viruses in TID such as the PCR for the detection of the viruses in pancreatic cells or the use of histopathology test. The data reported in this study regarding HCV antibodies showed the possible role of this virus in appearance and/or progression of T1D and it's possible that HCV infection may serve as an additional risk factor for the development of diabetes, the association between $\mathrm{HCV}$ infection and diabetes was conducted depending on the fact that diabetics have an increased frequency of HCV infection.

An association has been established between DM and HCV infection; however, it remains to be determined whether HCV infection leads to diabetes or vice versa.

\section{References}

1. Tisch R., McDevitt H. (1996).Insulin dependent diabetes mellitus. Cell 85; 291-297.

2. Kate L.G., Joanne A.O., Yan T., Natalie S., Emma M.C., Janette A. and Barbara S., (2007). Rota virus infection of infant and young adult nonobese diabetic mice involves extraintestinal spread and delays diabetes onset. Journal of virology, vol.81, no.12, p.6446-6458.

3. Pyke D.A., (1989). The genetic perspective-putting research in to practice. In Diabetes 1988, Larkins R.G., Zimmet P.Z., Chisholm D.J. (eds). Exerpta Medica: 1227-1230. Amsterdam.

4. Barnett H.A., Effel C., Leslie R.D.G., Pyke D.A., (1981). Diabetes in identical twins. A study of 200 pairs. Diabetologia 20; 87-93.

5. Vander N., Kroese F.G., rosing J., and Hillebrands J.L., (2007).viral infections as potential triggers of type -1- diabetes.Diabetes Metab.Res.Rev. 23:169-183.

6. Yoon J.W., Jun H.S., (2000). Role of viruses in the pathogenesis type 1 diabetes mellitus. In Diabetes Mellitus:A fundamental and clinical text ,LeRoith D, Olefsky M (eds.).Lippincott-Ravin;419-430. Philadelphia

7. Hee-SookJun and JiWon Y., (2002). A new look at viruses in type -1- diabetes. Diabetes/Metabolism Research and Reviews. 19:8-31. 
8. Christen U. and Von Herrath M.G., (2005). Infections and autoimmunity- good or bad?J. Immunol. 174:7481-7486.

9. Fujinami R.S., VonHerrath M.G., christen U. and Whitton J.L., (2006). Molecular mimicry by stander activation,or viral persistence :infections and autoimmune disease Clin.Microbiol.Rev. 19:80-94(Abstract/free full text).

10. Blomqvist M., Juhela S., Erkkila S., Korhonen S., Simell T., Kupila A., Vaarala O., Simell O., Knip M. and Ilonen J.,(2002). Rotaviruse infection and development of diabetes-associated autoantibodies during the first 2 years of life. Cli. Exp. Immunol 128:511-515.(CrossRef) (Medline)

11. Pak C.Y., Cha C.Y., Rajotte R.V., McArthur R.G., Yoon G.W., (1990). Human pancreatic islet cell-spesific $38 \mathrm{kDa}$ autoantigen identified by cytomegalovirus induced nonclonal islet cell autoantibody. Diabetologia 33;569-572.

12. Parkkonen F., Hyoty H., Ilonen J., Reijonen H., Yla-Herttuala S., Leinikki P.,(1994). Antibody reactivity to an Epstein-Barr virus BERF\$-encoded epitope occurring also in Asp-57 region of HLA-DQ8 $\beta$ chain. Clin Exp Immunol 95; 287-293.

13. Sairenji T., Daibata M., Sorli C., Qvistback H., Humphreys R.E., Ludvigsson J., Palmer J., landin-Olsson M., Sundkvist G., Michelsen B., lernmark A., Dyrberg T.,(1991). Relating homology between the Epstein-Barr virus BOLF1 molecule and HLA-DQw8 beta chain to recent onset type 1 (insulin dependent) diabetes mellitus. Diabetologia 34; 33-39.

14. Mason A.L., Lau J.Y., Hoang N., Qian K.P.,Alexander G.J., Xu L.Z., (1999).Association of DM and chronic HCV infection. Hepatology, February, Vol.29, No2, P.328-333.

15. Terrault and Khalili (1999). Hepatitis-C virus: Associated with new onset diabetes mellitus.Digestive disease week, Orlando, Fla, (Abstract L0457).

16. Konrad T., Zeuzem S., Vicini P., Toffollo G., Briem D., Lormann J.,( 2000). Evaluation of factors controlling glucose tolerance in patients with $\mathrm{HCV}$ infection before and after 4 months therapy with interferon - A. Eur J Clin Invest. 30(2):111121. 